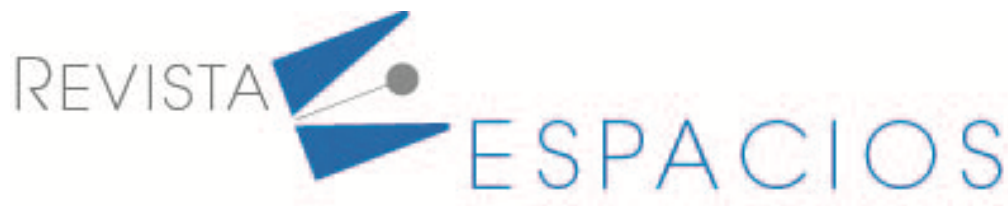

Vol. 42 (14) 2021 • Art. 5

\title{
Strategic direction and synergy: a case study of a Colombian insurance company
}

\section{Direccionamiento estratégico y sinergia: un caso estudio de una empresa colombiana de seguros}

\author{
GARCÍA, Martha L. ${ }^{1}$ \\ HOYOS, Pablo A. ${ }^{2}$ \\ CORTEZ, Plutarco A. ${ }^{3}$ \\ VARGAS Taborda, Libardo Carlos ${ }^{4}$ \\ MONTOYA, Alexa J. ${ }^{5}$
}

\begin{abstract}
Strategic management is essential in an organization from the identification of exogenous and endogenous factors to define its actions. The article shows a strategic management model for the commercial area of an insurance company in a branch in Colombia, based on the analysis of the shortcomings exposed by the company, to strategically structure and manage the commercial area with a perspective to increase sales and improve its local market share.

Key words: business management, strategic model, managerial processes

\section{Resumen}

La gestión estratégica es fundamental en una organización desde la identificación de factores exógenos y endógenos para definir su actuar. El artículo muestra un modelo de gestión estratégica para el área comercial de una empresa aseguradora en una sucursal en Colombia, a partir del análisis de las falencias expuestas por parte de la empresa, para estructurar y gestionar de manera estratégica el área comercial con perspectiva a incrementar las ventas y mejorar su participación en el mercado local.

Palabras clave: gestión empresarial, modelo estratégico, procesos gerenciales
\end{abstract}

\section{Introduction}

In the insurance sector, organizational structures are based on different processes; which leads to having a general vision of the company, and to know its strategic direction from the rationality that strategic management implies to meet the defined indicators and established goals, and thus, achieve the goals that the organization has set (Romo Morales \& Márquez de León , 2014). Context, which does not necessarily define whether the

\footnotetext{
${ }^{1}$ (C) Doctorado en Administración Gerencial. Universidad Benito Juárez. Maestría en Administración. Chile. Universidad La Gran Colombia - Docente Investigador de la Facultad de Ciencias Económicas, Administrativas y Contables. garcialonmartha@miugca.edu.co

${ }^{2}$ Ingeniero electrónico. Quindío. Universidad La Gran Colombia Armenia. Colombia. Pablohoyos93@gmail.com

${ }^{3}$ Ingeniero mecánico. Quindío. Universidad La Gran Colombia. Colombia. cortesmateus@gmail.com

${ }^{4}$ (C) Doctorado en Administración Gerencial. Universidad Benito Juárez. Colombia, Quindío. Universidad La Gran Colombia - Docente Investigador de la Facultad de Ciencias Económicas, Administrativas y Contables., vargastlibardocarlos@miugca.edu.co.vargastlibardocarlos@miugca.edu.co

${ }^{5}$ (C) Doctorado en Ciencias Económicas. Pontificia Universidad Javeriana. Docente. Quindío. Universidad del Quindío. Colombia.

mmalexa@uniquindio.edu.co
} 
entity prospects to be competitive or not, since the definitions of goals can focus on an area that should not be the focus of attention for organizational action. In this sense, it is appreciated that strategic management plays a significant role allowing to identify the influence of all exogenous and endogenous factors, which allow defining the entity's actions from the business mission and vision, which seek a level of competitiveness for finally achieve success and ensure the permanence of the company in the market, through strategic models (Wheelen \& Hunger, 2013). However, in the presence of an increasingly dynamic and fluctuating environment, competitiveness for organizations is more than an option, it is a necessity, since consumers are more specialized thanks to globalization itself and the media. For this reason, organizations must be orderly and make strategic decisions when offering a good or a service to the customer, taking into account the information and requirements of the environment to make the necessary adaptations (Rengarajan, Moser, \& Narayanamurthy, 2021). In this investigative process, a situational analysis of the commercial area of the Seguros del Estado company was carried out; to later design the strategic management model for the commercial area and its monitoring and control plan that adjusts to the needs of said company. Applying a type of descriptive study, under the deductive method, starting from the generalities until finding the particularities of the commercial area of the Seguros del Estado Armenia, where a mixed approach conjugation is made, for which it was necessary to have the approach with each of the advisors, so that from there the initiative of continuous improvement towards the competitiveness of this organization would be given.

\subsection{Overview of the insurance sector and quality}

The Federation of Colombian Insurers, (hereinafter: Fasecolda), raises some of the main variables of the sector, which are: premiums written, claims paid, premiums earned, claims incurred, brokerage commission, general expenses, technical results, product of investments, net income, assets, investments, accounting equity, premium retention, company account claims (SCC), SCC II, brokerage costs, efficiency, combined ratio, technical margin, profit, profitability, turnover, etc. (Fasecolda, 2018)

Additionally, at a specific level, other variables of great relevance are identified, such as: individual productivity of external business advisers, motivation (officials and external business advisors), workload, individual and collective performance, coexistence, teamwork, relationship and environment labor.

It is also inferred that, in order to be competitive at the organizational level and especially in the insurance sector, a large number of variables must be taken into account, where it is not feasible to handle non-articulated strategies that only lead to the achievement of solely financial goals, but to understand the organization from different inputs, generating multiple outputs, which contributes to the construction of the organizational action plan with a view to developing the objectives and goals outlined in a comprehensive and efficient manner. However, in the current context, the commercialization of intangible services has presented notable growth, mainly in the insurance sector, where at the end of 2016, there was a figure of $\$ 23.9$ billion and with a growth of $11.5 \%$ over the previous year. According to these figures, more than $\$ 16$ billion are returned in claims payments (Dinero, 2017). On the other hand, the same publication refers to the interview of the president of Seguros Mundial, Juan Enrique Bustamante, who states that for 17 years the growth of the insurance industry has been very interesting: it has grown $12.3 \%$ on average, while GDP has increased $9 \%$. Insurance penetration went from $1.78 \%$ to $2.79 \%$ (Dinero, 2017). In this sense, the insurance sector has a relevant participation, since it presents the highest annual growth rate in the Colombian economy, which corresponds to $6.1 \%$ for the first quarter of 2018 (Dinero, 2017). Likewise, in 2019 the Colombian insurance industry will experience better performance compared to the records of 2018. In fact, in the first half of this year its growth was $8.3 \%$, compared to $5.1 \%$ of the first half of last year, a significant figure. Consequently, this economic outlook denotes a growth of 3.3\% (Portafolio, 2019). Now, the insurance sector in Colombia has two large subdivisions, which are Life and General; In the Life sector there are all the products that ensure the protection of life and / or the integrity of 
the person, on the other hand, the General category includes all the products related to loss and material damage. Within this sector with great potential, Seguros del Estado shows a growth of $10.3 \%$ and has a share in the general market of $10.6 \%$, which places state insurance in second place in sales in the general lines in the nation. Likewise, the profitability of national entities in the two branches is presented, in which a parallel is made of the income results of each of the entities, corroborating that Seguros del Estado Company is a constant entity in terms of this factor, evidencing a slight increase in profitability for the periods compared, which places it above the average in profitability. Despite its good position in the national scene, the Armenia, Quindío branch of state insurance shows growth below the company's average. Hence, its participation in the local market is $12.4 \%$, ranking second below Suramericana in the city of Armenia. In addition, in a contrastive framework, it is noteworthy that $35 \%$ of the total number of branches showed a higher growth than that of the branch located in Armenia.

It is noteworthy that until now, the model applied by the branch does not allow for articulated work, nor adequate planning, because the commercial area is made up of a high percentage of external agents, where the sales force is based largely on the benefits of commercial products and not on the methodical work of the commercial areas involved, which is an unfavorable point in its management, given that it is not prepared for times of low market demand. According to commercial closure figures of the Seguros del Estado Armenia branch, 45\% of the sales that the office presented in 2019 at the end of December, correspond to branches that basically do not require commercial work, such as the mandatory branch of SOAT and Compliance, from this it can be extracted that the remaining $55 \%$ of sales are not controlled or managed in the best way to extract the maximum potential from the commercial area. In fact, the relationship with quality models and processes to achieve the competitiveness of organizations, guides us to strive for continuous improvement as well mentioned (Álvarez Martínez \& Rebosa Álvarez, 2004), who encourages us to reflect on quality supported by the Jurán's thought cited by (Medina \& Gozalbes Ballester, 1996), where the characteristics of the user are considered and recognized as usual or beneficial with adaptation to use. It is also worth noting that the Juran philosophy includes the following aspects: Quality is the suitability for use and complying with technical and human specifications; The need to implement annual improvement programs; Massive training in quality models (Álvarez Martínez \& Rebosa Álvarez, 2004). Another look at quality is the philosophy of Edward Deming cited (Evans \& Lindsay, 2010), who from his perspective argues that variation is the main cause of the reduction in quality (quality is a high degree of uniformity in the production). To achieve a reduction in variation, Deming resorted to a permanent cycle consisting of: product or service design, manufacturing or service provision, testing and sales, followed by market research and redesign and improvement. With the above, Deming argues that higher quality leads to better productivity and a long-term competitive strength as presented in Figure 1.

Figure 1

Suitability of use

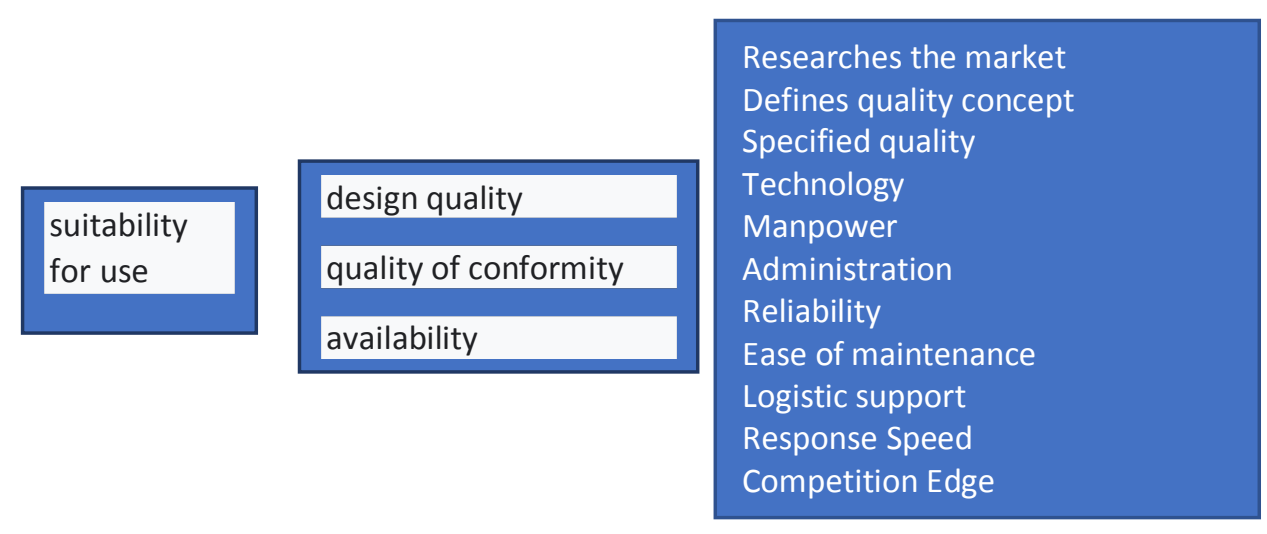

Source: Evans, 2010 
As seen from the total quality, a multidimensional visual can be added to the search for excellence throughout the entire value creation chain oriented towards the market and the client, thus providing organizations with an integrative and interdisciplinary as seen in Mercadona's work (Blanco, 2008).

Additionally, when developing strengths in the organization, sociological factors cannot be ignored, as Ariel De Geus relates in his work The Living Company, where he refers to his clients (internal and external), mentioning: "The fundamental contract between the company and its members is that members will be helped to reach their potency. It's understood that this, is in the company's own interest. This emerges from their knowledge that member potential helps create corporate potential" (Geus, 1998)

Therefore, the lack of clear and homogeneous processes within the organization does not allow the commercialization of strategic products proposed by senior management, which generates a continuous lack of harmony with their world, which will lead to a crisis that can be mortal (Geus, 1998).

On the other hand, reference is also made to the relationship with the environment, indicating that: the processes of the commercialization of intangibles can be developed intuitively and without any type of defined methodology, but it is clear that having processes properly established and methodologies with constant monitoring that involve management indicators that are measurable at all times, offer greater potential in the results of commercial management.

The situation presented leads to the analysis of the shortcomings exposed by the Armenia branch, and to studying the potential of the market in which said branch operates. Consequently, it is relevant to strategically structure and manage the commercial area, whose prospect is to increase the annual sales growth rate and improve its participation in the local market.

\subsection{Strategic management: key element towards competitiveness}

\subsubsection{Applied strategic planning model}

The model developed by (Goodstein, Nolan, \& William, 1998), which starts from establishing the implementation phases of the strategies, shows in a particular way the adaptation in small and medium-sized organizations; where the expansion of the nine sequential phases that comprise it, can be developed in a fluid way, given the interactions of the organization with its members. This model starts from planning, search for values, formulation of the mission, design of the business strategy, performance audit, in which the strengths and weaknesses of the organization are analyzed, gap analysis, in order to establish the differentiations of the organizational one, which contributes to the integration of action plans, which must be detailed and achieving an adequate structure for the fulfillment of the organizational objectives, however, this cannot be alone but accompanied by a contingency plan, to respond to eventualities, which may be of internal or external origin, in addition to evaluating the impact and managing risk. Similarly, the implementation, in the development of tactical and operational plans, communication, managerial controls and compensation programs that support the strategic plan, tools and training. The authors state that deciding the future course of an organization is the task of senior management, which cannot and should not be delegated (Goodstein, Nolan, \& William, 1998).

\subsubsection{Russel Ackoff model}

Russell's model shows us the need to understand the origin of changes in a Global way, that is, contemplating the new avant-garde methodologies of each era. Russel, highlights, the importance of planning, since when it is not planned, it cannot be avoided that the planning of others or their organizations reaches us.

Russel shows 3 principles that are the basis for developing his model, such as: Participatory Principle: only by actively participating in the planning process, the members of the organization achieve their organizational development. Principle of Continuity: every plan is susceptible to failures, no matter that the best methodologies 
have been developed in its planning. This is why permanent observation of the execution of the plan is of great importance. And finally the Holistic Principles: The principle of related coordination and integration, are planned simultaneously and interdependently to achieve better results. The Russell Ackoff Model helps us understand that the most efficient and effective way to use a strategic model in a company is to continuously develop planning since thanks to this, the company will be constantly updated with its environment and fixed with precision what is going to be done (Ackoff, 2005)

\subsubsection{Igor Ansoff's model}

Ansoff represents a conceptual framework for discontinuity management, likewise, a systematic approach to strategic decision making, as well as a methodology to guide implementation. This model involves issues such as environmental issues in its analysis; evaluation of response systems, strategic posture and the strategic event management system. As well as establishes in its matrix four basic strategies for companies to improve their growth in sales and greater market share through adequate market penetration, market development, product development, and diversification, key mechanisms for grow in the industry (Ansoff, 1985)

\subsubsection{Michael Porter model}

This model is based on the importance of conducting a competitive analysis, both in the formulation of company strategies and in its corporate finances. Porter highlights that each organization has its own strategy and in turn each strategy depends on the policies and means to achieve it. In his model, Porter points out the importance of competitive strategies, since from these, internal factors such as the strengths and weaknesses of the organization and external factors such as opportunities and threats arise (Porter, 2008). According to the author, the competition is the set of companies that are dedicated to providing the same product or service in the same market.

\subsubsection{Yousef Haik and Tamer Shanin functional model}

For its part, the functional analysis of (Haik \& Tamer, 2011), proposes a more scientific view of design, being a method with a systematic approach in logical sequence, where it starts from a main function, identification of variables (both inputs and outputs of our system) and disaggregation into subfunctions. All this functional analysis includes the black box model, transparent box model, functional tree and the identification of the flows of matter, energy and / or information. The black box and transparent box models are closely interrelated; The black box model considers the main function, the inputs and the outputs of the system, where the main function is the one that describes what the whole system does and is expressed with a verb and a noun. On the other hand, the transparent box makes a relation of the tree of functions with the inputs and outputs of the system. The functional tree presents a disaggregation of the main function (subfunctions) and a logical interrelation, which is called a functional tree, where the actions, flows and sequences required to achieve that main function are identified.

\section{Methodology}

The research method used is deductive with a mixed approach in which the generalities presented by the commercial area and the particular analysis phenomena that will allow obtaining the information in a specific way are established. Likewise, observation becomes an essential parameter, in order to know the performance of the external and internal advisers of the commercial area and the performance in relation to the strategies that are being developed. The research is descriptive where the phenomena and particularities that occur in the commercial area are studied, from their respective strategic management.

The population under study is made up of various organizational levels, where there is the vice presidency composed of 1 vice president and 15 collaborators, the management of the offices, the commercial managers, 
in the Seguros del Estado Armenia there are two commercial managers and 71 external advisors. The sample with a confidence level of $95 \%$ and a margin of error of $7 \%$, yielded as a result a total of 53 external consultants to carry out the survey; Regarding the interview, it was applied to the vice president of the company. The information obtained through surveys and interviews must be contrasted with secondary data, in order to identify gaps in the processes currently being developed in the Armenia branch state insurance. The information for the aforementioned process must be tabulated, analyzed (frequencies, means, medians, modes) and graphed in order to identify needs and motivations in the population under study, to later proceed to feed the SWOT matrix in order to complete the business diagnosis and thus determine from the characterization the appropriate management model in this context.

\section{Results and discussion}

\subsection{Business diagnosis}

Seguros del Estado is a national company with more than 64 years in the market and with extensive experience and specialization in underwriting Compliance Insurance, Automobiles, Civil Liability, SOAT, Material Damage, Machinery and Equipment, Personal Accidents, Life Individual and Group, its objective is to protect the heritage of Colombians; by means of products designed according to the risks that may affect it, with the support of the first-line Multinational Reinsurers.

Seguros del Estado's mission is to satisfy the different protection needs of Colombians and their companies, always trying to be one of the most solid and efficient companies in the Colombian insurance sector, maintaining leadership in the General and Personal Insurance lines.

Currently, according to (Blanco, 2008), who establishes that state insurance makes more than 95\% of its sales, supported by its independent commercial force, which is made up of independent advisers, insurance agencies and brokers; Likewise, they have commercial links with other companies in the sector and therefore can present at the disposal of the final buyer, a varied range of proposals, for the same risk to insure.

The Armenia-Quindio branch currently leads in the market, in the compliance and SOAT branches, branches that do not require extensive commercial performance by the sales force, in the same way it has great possibilities of growing in the branches that require a more commercial process. wide, as is the one of the Life branches, where it is located in the tenth place of the Fasecolda ranking.

The commercial area of the Seguros del Estado Armenia branch depends on the management of the branch and has two commercial managers, who jointly manage a total of 74 external advisors, who are in charge of the commercialization of $92 \%$ of the sales of the office. The commercial manager is in charge of directly meeting the needs and requirements of the commercial force and being a bridge to the other areas of the company.

In State insurance, it is evident that the lack of trained personnel and the absence of a training school for external advisers, this situation permeates the ideal strategic development of the organization, added to it the lack of sense of relevance by the institution for part of the sales force, the deficiency in the workforce in supervision processes among other variables that it suffers from and the ignorance of the change in the commercialization processes, denotes a discouraging outlook for its strategic growth. Next, a situation analysis of the organization under study is made by establishing the critical, passive, active and indifferent points of state insurance through the Vester matrix. 
Figure 2

Vester Matrix

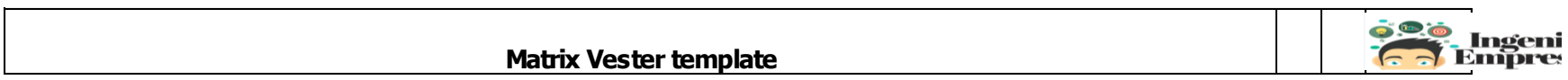

\section{Problematic situation}

Incipient visibility of the application of sustainability public policy strategies from government, business and society in the context of tourism and comprehensive management of the territory in relation to sustainable development

\begin{tabular}{|c|c|c|c|c|c|c|c|c|c|c|c|c|c|c|}
\hline Code & Variable & P1 & P2 & P3 & P4 & P5 & P6 & P7 & P8 & P9 & P10 & P11 & P12 & INFLUENCIA \\
\hline P1 & Badly filled out stationery & 0 & 1 & 1 & 0 & 0 & 0 & 0 & 2 & 0 & 2 & 0 & 3 & 6 \\
\hline P2 & Use of outdated formats & 3 & 0 & 0 & 0 & 0 & 0 & 0 & 0 & 0 & 2 & 0 & 3 & 5 \\
\hline P3 & Lack of knowledge of changes in the marketing process & 3 & 3 & 0 & 1 & 3 & 0 & 0 & 2 & 0 & 3 & 0 & 3 & 15 \\
\hline P4 & Poorly trained staff & 3 & 3 & 3 & 0 & 3 & 0 & 0 & 3 & 2 & 3 & 0 & 3 & 20 \\
\hline P5 & Lack of knowledge of the comprehensive portfolio & 0 & 1 & 3 & 1 & 0 & 0 & 0 & 1 & 0 & 3 & 1 & 2 & 9 \\
\hline P6 & Absence of training school & 3 & 3 & 3 & 3 & 3 & 0 & 0 & 1 & 2 & 3 & 1 & 3 & 21 \\
\hline P7 & Deficiency in manpower to supervise external consultants & 3 & 3 & 2 & 2 & 2 & 0 & 0 & 3 & 2 & 3 & 2 & 3 & 20 \\
\hline P8 & Withholding of premiums (fraud) & 3 & 2 & 0 & 0 & 0 & 0 & 0 & 0 & 1 & 3 & 0 & 1 & 9 \\
\hline P9 & Lack of a sense of belonging & 2 & 2 & 3 & 2 & 3 & 0 & 0 & 3 & 0 & 2 & 2 & 3 & 17 \\
\hline $\mathrm{P} 10$ & Incomplete Attachments & 2 & 0 & 0 & 0 & 0 & 0 & 0 & 0 & 0 & 0 & 0 & 3 & 2 \\
\hline $\mathrm{P} 11$ & Staff disinterest in the prizes offered & 0 & 0 & 1 & 1 & 2 & 0 & 0 & 2 & 2 & 0 & 0 & 1 & 8 \\
\hline $\mathrm{P} 12$ & Deficiencies in the Underwriting Process (Business Risk Assessment) & 2 & 1 & 0 & 1 & 0 & 0 & 0 & 0 & 0 & 3 & 0 & 0 & 7 \\
\hline & DEPENDENCE & 24 & 19 & 16 & 11 & 16 & 0 & 0 & 17 & 9 & 27 & 6 & 28 & 86 \\
\hline
\end{tabular}

Source: Own elaboration supported by the Vester matrix.

Figure 3

Decision quadrants

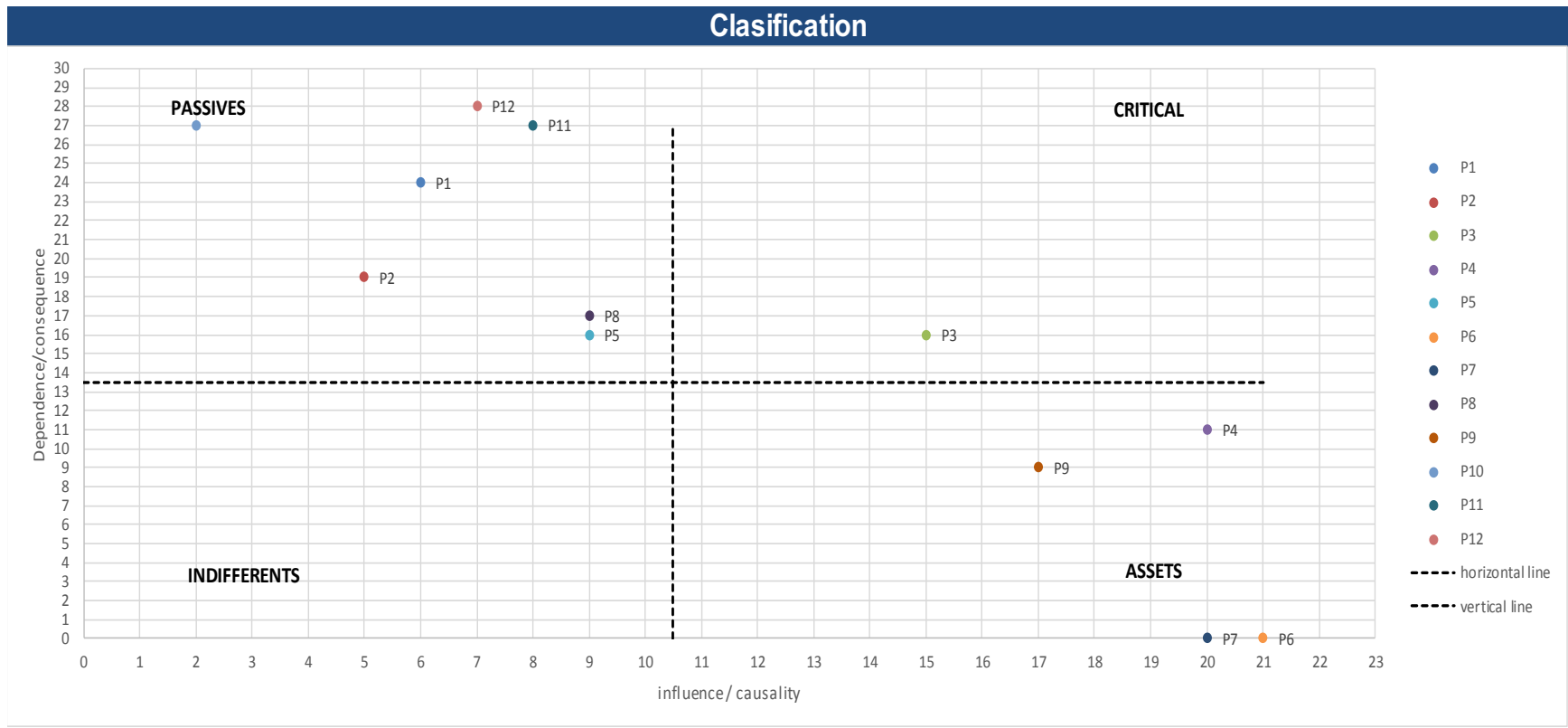

Source: Own elaboration supported by the Vester matrix

According to the results obtained from the analysis of the commercial area and especially in the external sales force, a breakdown is made of the activities carried out by the external sales force in each of the stages or processes in which they participate. It should be emphasized that in order to have a broad view of the current context in State Insurance, the difficulties were identified from the strategic mentality of the top management, where deficiencies in knowledge of both the organizational processes and company products area - are evident.

In the process or activities of commercial contact, it is identified that some of the advisors have deficiencies in technical and organizational knowledge, which can generate the offer or sale of products that are not suitable for the needs of the clients and additionally reprocesses and loss of clients; at this stage the presence of the risk 
of fraud and moral hazard is identified (it should be clarified that these risks do not materialize on a daily basis but are identified as potential, which is why they are added in the analysis)

Regarding risk analysis, in matters of difficulties, reprocessing is the most representative, where the bad collection of documentation, requirements, needs and technical reality of the client generated by failure in the extraction of client information, both personal and technical and financial, accompanied by the lack of knowledge of the portfolio due to the poor management that is given, makes the product offer inadequate for the reality of the client and lost for the company represented in man-hours. However, since the closing of the business, the great difficulties are related to the lack of integrity and clarity with the client, due to the low explanation in the information of the contracted products (this includes all legal conditions, technical conditions and forms of pay). From the integrality, it can be seen that he focuses on the sale of few products in the portfolio, just as he does not easily identify potential business or latent needs in the client, which represents the loss of future or potential sales for the organization.

Table 1

Participation of external advisers in organizational processes.

\begin{tabular}{|c|c|c|c|c|}
\hline \multirow{2}{*}{ 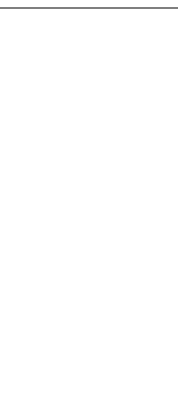 } & & Comercial Contact & Risk Analisis & Business Closure \\
\hline & Participation & $\begin{array}{l}\text { Business prospecting } \\
\text { Search or achievement } \\
\text { of clients (referral, door } \\
\text { to Closure door or } \\
\text { prospecting } \\
\text { Interaction with the } \\
\text { client. }\end{array}$ & $\begin{array}{l}\text { Presentation of the } \\
\text { offer. } \\
\text { Determination of } \\
\text { requirements and } \\
\text { Needs. } \\
\text { Extraction of } \\
\text { customer } \\
\text { information. }\end{array}$ & $\begin{array}{l}\text { Presentation of the quote. } \\
\text { Business Signature. } \\
\text { Collection of documents. } \\
\text { Definition of payment } \\
\text { methods. } \\
\text { Loyalty. } \\
\text { Integrality of the clients. }\end{array}$ \\
\hline $\begin{array}{l}\text { External } \\
\text { Sales Force } \\
\text { (ESF) }\end{array}$ & Difficulties & $\begin{array}{l}\text { Knowledge of the } \\
\text { business by the advisor, } \\
\text { since it is possible to try } \\
\text { to insure things that are } \\
\text { not insurable. } \\
\text { Moral risk, ignorance of } \\
\text { the person to be } \\
\text { insured. } \\
\text { Risk of fraud with the } \\
\text { client due to poor study } \\
\text { by the advisor (related } \\
\text { to the previous point). } \\
\text { Payment capacity is not } \\
\text { identified. }\end{array}$ & $\begin{array}{l}\text { Not offering the } \\
\text { right product. } \\
\text { Lack of knowledge } \\
\text { of the portfolio and } \\
\text { the true needs of } \\
\text { the client. } \\
\text { The necessary or } \\
\text { useful information } \\
\text { for the technical } \\
\text { area is not } \\
\text { extracted. }\end{array}$ & $\begin{array}{l}\text { The information necessary for } \\
\text { the issuance of the policy is } \\
\text { not collected. } \\
\text { There are no defined times or } \\
\text { form of payment. } \\
\text { Various things are omitted in } \\
\text { the explanation of the final } \\
\text { product. } \\
\text { No more business is sought for } \\
\text { the client } \\
\text { (comprehensiveness). }\end{array}$ \\
\hline
\end{tabular}

Source: Own elaboration

For this phase it is important to support the project of strategic tools that allows a general and practical diagnosis of its strengths, weaknesses and to identify, from its current potential, the better decisions by anticipating internal and external factors. To achieve this, use is made of the SWOT matrix and the PEYEA matrix, which will generate a diagnosis, solutions to various problems identified and allow a strategic selection of solutions based on the current State Insurance against the market and various contexts (variables environmental, economic, internal, external context, etc.).

From the competitive advantages dimension, it is found that Seguros del Estado is an organization that is venturing into new technologies and developments, leveraged on market participation, thanks to its wide 
portfolio of products, which is sustained due to the quality relationship -Price, hand in hand with the experience of the staff and the good relationship with the suppliers. Additionally, it is noteworthy that Seguros del Estado currently has 5 million policyholders, 1,450 employees and 4,280 intermediaries that feed 95 percent of its portfolio, in addition to this huge network of advisors, a key factor in its success is having all branches and have specialized in different niches. For example, it is a leader in the surety segment, with a 25 percent share in this market, as well as in SOAT, with 33 percent (Revista Semana , 2020).

Regarding the environmental aspect, it presents stability according to the great changes generated by the national crisis and the variation in the TRM (as well as inflation), factors that negatively impact the organization and the demand for products in the market.

Regarding the strengths of the industry, being a solid organization with a good financial position and a broad portfolio of products, competitiveness and the prospect of expanding the market niche that allows growth and expansion is appreciated. Below is the table with the respective dimensions, variables and qualification of the analysis of the organization.

Table 2

PEYEA Variables

\begin{tabular}{|c|c|c|}
\hline Dimention & Variables & Calificaction \\
\hline \multirow[t]{7}{*}{ Finanacial Strengths } & Return on Assets & 3 \\
\hline & Return on Shared Assets & 2 \\
\hline & Working Capital & 5 \\
\hline & Liquity & 4 \\
\hline & Utility & 2 \\
\hline & Combined index & 1 \\
\hline & Average Qualification & 2,83 \\
\hline \multirow[t]{8}{*}{ Competetive Advantages } & Leadership in Technology & -4 \\
\hline & Service Quality & -2 \\
\hline & Participation in the market & -2 \\
\hline & Relationship with suppliers & -2 \\
\hline & Leadership in costs & -2 \\
\hline & Personal Experiences & -2 \\
\hline & Service portfolio & -2 \\
\hline & Average Qualification & $-2,28$ \\
\hline \multirow[t]{7}{*}{ Enviormental Stability } & National Crisis (Economic, social y salud) & -4 \\
\hline & Inflation & -3 \\
\hline & Value of COP vs Value of USD & -4 \\
\hline & Competetive Pressure & -2 \\
\hline & Govvernment Politics & -2 \\
\hline & Supply-Demand Relationship & -3 \\
\hline & Average Qualification & -3 \\
\hline \multirow[t]{8}{*}{ Strength in the Industry } & Growth Potential & 4 \\
\hline & Profit potential & 4 \\
\hline & Fnancial stability & 5 \\
\hline & Knowledge & 3 \\
\hline & Easy entrence into the marketsz & 5 \\
\hline & Access to new technology & 4 \\
\hline & Barganing power & 5 \\
\hline & Average Qualification & 4,28 \\
\hline
\end{tabular}


When carrying out the exercise, it is found that for state insurance the most advisable thing is to implement competitive strategies, as shown in Figure 4, where an idea of continuous growth in various aspects that the organization seeks is linked. With this, it can be identified that it is feasible to implement combined strategies in order to achieve a better positioning against the competition.

Figure 4

PEYEA Matrix Evaluation

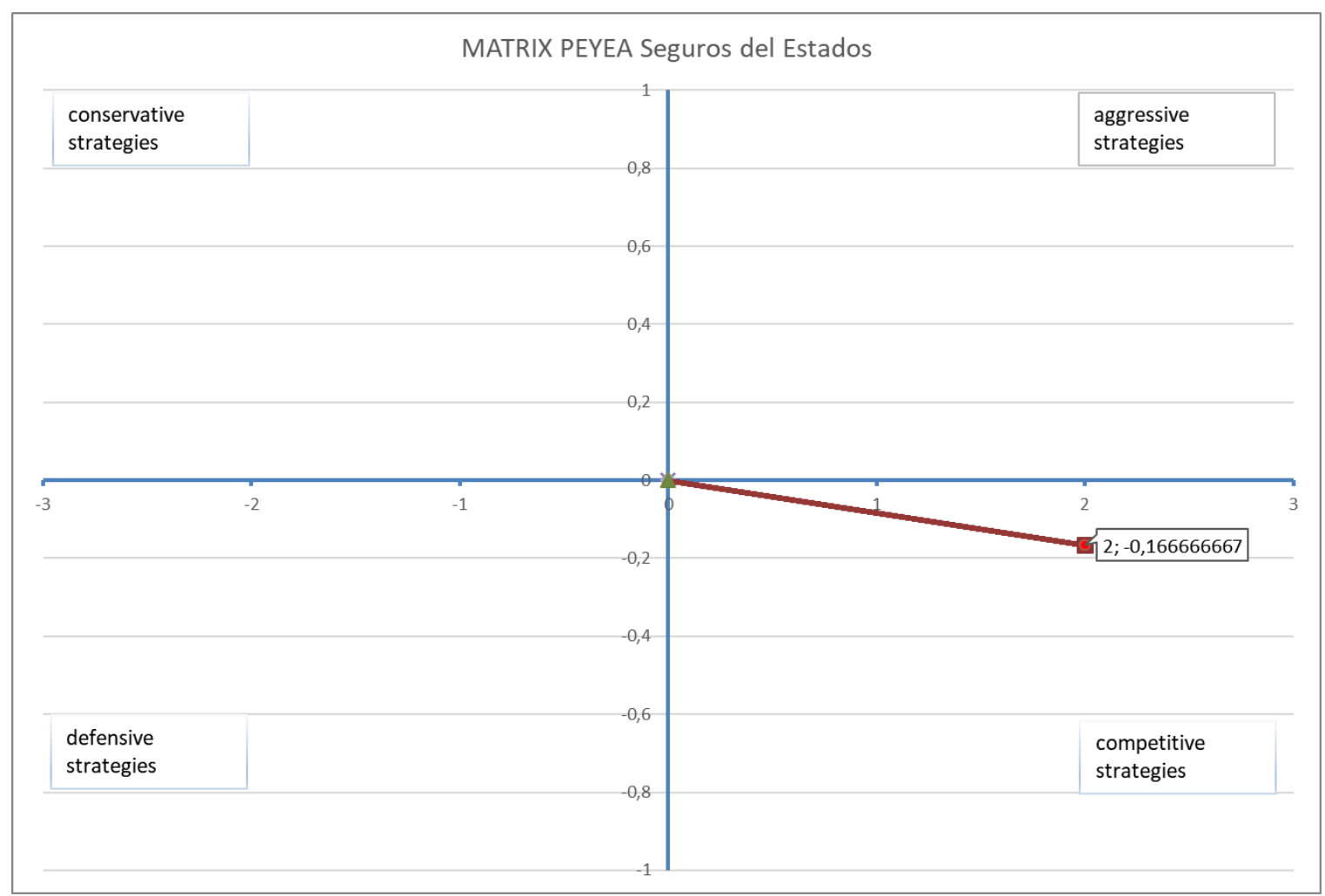

Source: Own elaboration supported by the thought of Fred David.

\section{Strategic model}

The Balance Scorecard is currently an important management tool in organizations, which allows to measure, evaluate and manage the evolution of the organization; facilitating decision-making, because the information is focused on a single report that contains all the relevant aspects that can be evaluated, which becomes a fundamental parameter to improve the strategic direction of the state's insurance (Norton \& Kaplan, 1996). Next, supported by the functional black box model, it is possible to identify the macro visuality of the general process of the company, in which the variables that interact to generate results and value are appreciated (figure 5). Additionally, the main actors in the value chain can be identified to achieve financial results (profitability), number of sales (Policies issued) and effectiveness of the commercial area (Policies issued - policies not issued). Therefore, understanding organizations as a black box (Haik \& Tamer, 2011), is based on combining multiple variables of the environment: government, customers, suppliers, among others, that directly and indirectly influence business performance, - which allows the leader of the organization to have a better appreciation to define and visualize the functional structure, as well as to evaluate the various fronts such as commercialization, marketing, compensation, etc. 
Figure 5

Black box functional diagram

coupled to State Insurance

\section{Inputs}

Customers

Technical notes

Advertising

External sales force

subscription policy

Risk

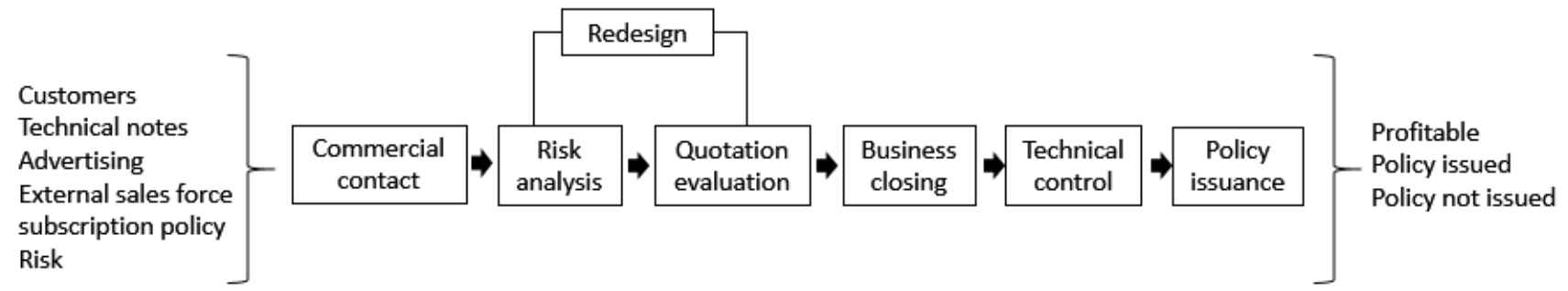

Source: Own elaboration.

If we proceed to broaden the visual spectrum of this model, we will find the transparent box diagram, which presents the disaggregation of functions and allows us to appreciate the flow of information and the channels of interaction between agents (both internal and external). In fact, this transparent box diagram, taken to the State Insurance business case, allows identifying critical points that depend on the external sales force. Hence, it is obvious that the first critical point is the commercial contact, where the external advisor, through different methodologies, manages to establish potential businesses, in which a survey is carried out of business information (taking into account customer requirements) and various relationship activities that strengthen business relationships with the customer.

The next point, where the advisor interacts, the risk analysis is made, and the necessary information of the business is supplied for its evaluation, assessment and management by the technical area of State Insurance.

Finally, the external advisor participates in the closing of the business, where the product is presented, which is the result of the process carried out by the technical area to proceed with the completion of the final documentation and legal documents. From the above, it can be extracted that the external advisers have communication channels with the technical area that can be direct or with the commercial manager as mediator, in which the commercial manager who is in charge of processing all their requirements, with the manager makes the closing of business proceed.

Likewise, it was convenient to use a contribution to state insurance through the design of the road map model which was developed based on Juran's thinking in his road map, in which various strategic tools are adopted, in addition to that. the conception of Fred David, which encourages internal and external analysis in which the organization operates, under the use of matrices such as PEYEA and VESTER. Hence, the intention of integrating these tools to be able to generate criteria in decision-making for the strategic approach that guides towards the 
execution of strategies, which become a stage for the development of goal setting, policy setting and activities. resource allocation. Likewise, it is necessary to carry out the evaluation of strategies from analyzing the internal and external factors that represent the bases of the current strategies; measure the organization's performance (as planned) and take corrective action to verify the course of action (David, 2003)

Consequently, the design of the tactical and operational plans, communication, management controls and compensation programs that support the strategic plan, tools and training were studied, these being fundamental elements for the fulfillment of the strategic objectives. In fact, some authors express that deciding the future course of an organization is the task of senior management, which cannot and should not be delegated (Goodstein, Nolan, \& William, 1998). Next, it is necessary to bring up the thinking of the Russell Ackoff model, which allows us to understand that the most efficient and effective way to use a strategic model in a company in which it must be continually planned, hence it is evidenced in the road mapping model that gives a fundamental guideline for the organization to be up-to-date with its environment and precisely fixes what is going to be done in state insurance (Ackoff, 2005). In this same sense, Porter highlights that each organization has its own strategy and in turn each strategy depends on the policies and means to achieve it. In his model, Porter points out the importance of competitive strategies, since from these, internal factors such as the strengths and weaknesses of the organization and external factors such as opportunities and threats arise. (Porter, 2008)

Figure 7

Road Map - Strategic Model Proposal

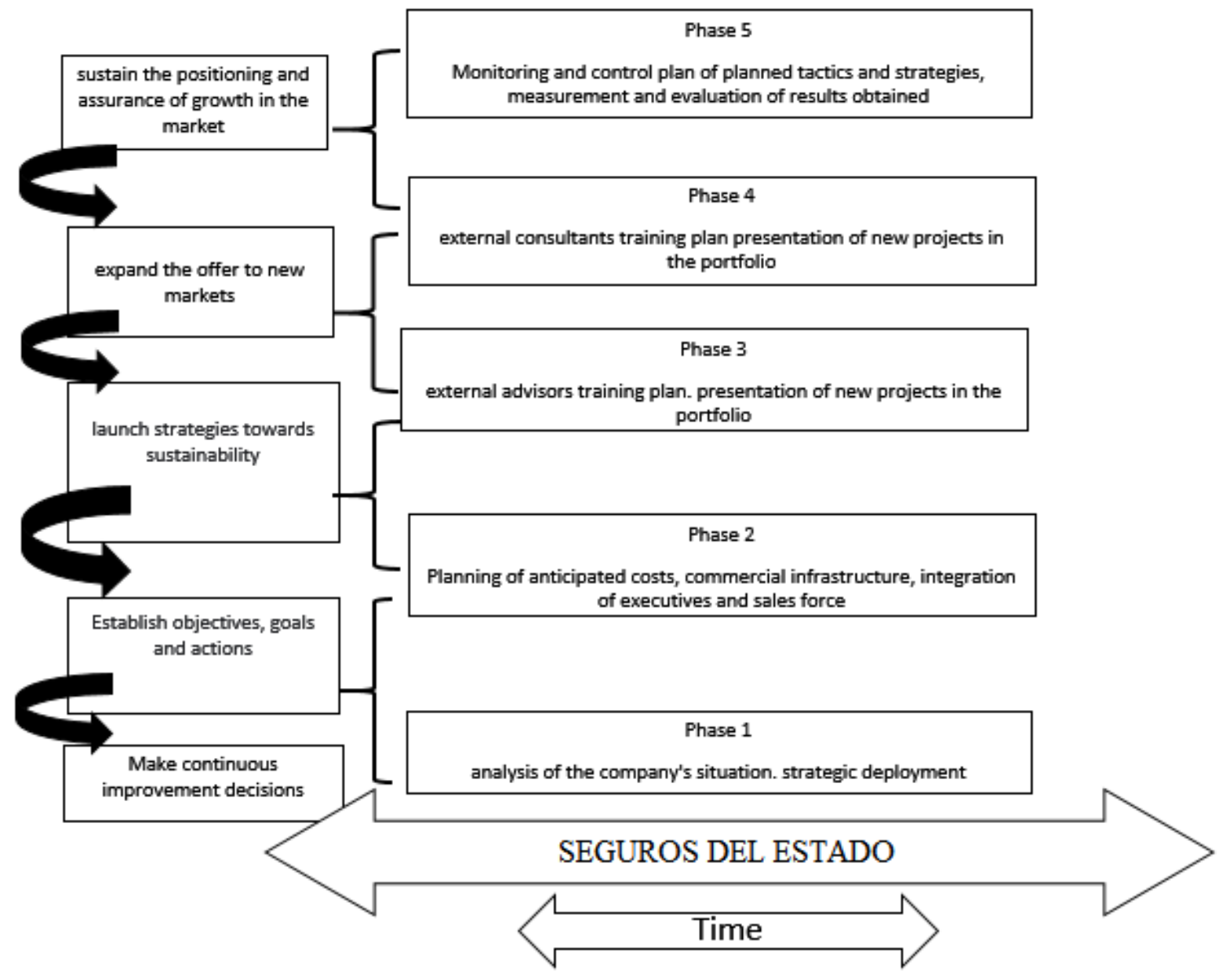

Source: Own elaboration supported by Juran (Gryna, Chua, \& Defeo, 2007) 
The researchers start from the construction of the strategic map from the conception of the road map of Juran which can be seen in Figure 6, where it must begin with the delimitation of the scope of the project, since it will only arrive at the planning and dimensioning of the methodology in which each of the phases contemplated in the model must be approached, in such a way that it induces state insurance companies to continuous improvement of the commercial area and sustainable growth of the organization.

Table 3

Proposed strategies

\begin{tabular}{|c|c|c|c|}
\hline Strategy SW & Strategy ST & Strategy OW & Strategy OT \\
\hline $\begin{array}{l}\text { initiate chat rooms with the } \\
\text { external advisor in a } \\
\text { collaborative way, with the } \\
\text { help of the plant staff, } \\
\text { focused on the } \\
\text { comprehensiveness of the } \\
\text { business and the assessment } \\
\text { of opportunities }\end{array}$ & $\begin{array}{l}\text { Through technical training of } \\
\text { the products to the staff, can } \\
\text { highlight the cost-benefit } \\
\text { relationship in front of the } \\
\text { client }\end{array}$ & $\begin{array}{l}\text { Improving the technological } \\
\text { platform, can give more } \\
\text { follow-up to business }\end{array}$ & $\begin{array}{l}\text { improve the platform to } \\
\text { streamline processes }\end{array}$ \\
\hline $\begin{array}{l}\text { adapt the self-management } \\
\text { platform so that automatic } \\
\text { renewal is carried out by each } \\
\text { advisor }\end{array}$ & $\begin{array}{l}\text { facilitate the subscription } \\
\text { processes through } \\
\text { improvements on the self- } \\
\text { management platform }\end{array}$ & $\begin{array}{l}\text { Implementing a training plan } \\
\text { well directed to the needs of } \\
\text { the branch advisor and the } \\
\text { client, allows addressing issues } \\
\text { of integrity, customer service, } \\
\text { methodological processes, etc. }\end{array}$ & $\begin{array}{l}\text { enable the platform for agile } \\
\text { self-management of external } \\
\text { consultants in subscription and } \\
\text { issuance processes }\end{array}$ \\
\hline $\begin{array}{l}\text { conduct surveys of the quality } \\
\text { and opportunity for } \\
\text { improvement, of the self- } \\
\text { management platform of the } \\
\text { sales force }\end{array}$ & $\begin{array}{l}\text { strengthen the commercial } \\
\text { accommodation, with a } \\
\text { collaborative work between } \\
\text { the commercial manager and } \\
\text { the process leaders }\end{array}$ & $\begin{array}{l}\text { request a delegation to the } \\
\text { general management for the } \\
\text { attention of claims in the } \\
\text { branch }\end{array}$ & $\begin{array}{l}\text { generate management } \\
\text { methodologies for the } \\
\text { commercial area }\end{array}$ \\
\hline $\begin{array}{l}\text { generate management } \\
\text { methodologies for the } \\
\text { commercial area }\end{array}$ & $\begin{array}{l}\text { Take advantage of the } \\
\text { closeness of the advisers to all } \\
\text { areas, to provide support in } \\
\text { the management }\end{array}$ & $\begin{array}{l}\text { generate methodologies for } \\
\text { the management of the } \\
\text { commercial area }\end{array}$ & $\begin{array}{l}\text { improve subscription } \\
\text { processes for personalized } \\
\text { products that require little } \\
\text { documentation }\end{array}$ \\
\hline $\begin{array}{l}\text { Add to the company's annual } \\
\text { awards plan some benefits } \\
\text { based on the } \\
\text { comprehensiveness of the } \\
\text { advisors and the } \\
\text { comprehensiveness of the } \\
\text { clients }\end{array}$ & $\begin{array}{l}\text { take advantage of flexibility for } \\
\text { product customization }\end{array}$ & $\begin{array}{l}\text { Reduce management times in } \\
\text { the office due to the fact that } \\
\text { the processes are carried out } \\
\text { automatically }\end{array}$ & $\begin{array}{l}\text { process in front of the general } \\
\text { management the delegation } \\
\text { and autonomy for the branch } \\
\text { in the attention of claims }\end{array}$ \\
\hline $\begin{array}{l}\text { development in the self- } \\
\text { management platform to } \\
\text { provide agility in processes } \\
\text { that depend on general } \\
\text { management and / or the } \\
\text { branch }\end{array}$ & $\begin{array}{l}\text { request to the general } \\
\text { management, delegation or to } \\
\text { the attention of claims in the } \\
\text { branch given the } \\
\text { organizational structure }\end{array}$ & $\begin{array}{l}\text { reduction of workload with } \\
\text { automation of renovations }\end{array}$ & $\begin{array}{l}\text { add topic and activities for the } \\
\text { management and control of } \\
\text { stress and relationship in the } \\
\text { training program }\end{array}$ \\
\hline $\begin{array}{l}\text { carry out follow-up by each } \\
\text { technical leader of the } \\
\text { commercial processes (in this } \\
\text { moment everything is } \\
\text { attempted by the commercial } \\
\text { manager, which is why you } \\
\text { can seek teamwork leaders- } \\
\text { manager }\end{array}$ & $\begin{array}{l}\text { generate management } \\
\text { methodologies supported by } \\
\text { each of the process leaders } \\
\text { and the commercial manager }\end{array}$ & & $\begin{array}{l}\text { carries out technical training } \\
\text { on the company's products } \\
\text { and on commercial issues that } \\
\text { leverage the closing and } \\
\text { generation of sales }\end{array}$ \\
\hline $\begin{array}{l}\text { Take advantage of } \\
\text { technological tools in } \\
\text { personalized processes, for }\end{array}$ & $\begin{array}{l}\text { conduct customer service } \\
\text { training }\end{array}$ & & \\
\hline
\end{tabular}




\begin{tabular}{|c|c|c|c|}
\hline Strategy SW & Strategy ST & Strategy OW & Strategy OT \\
\hline $\begin{array}{l}\text { the standardization of } \\
\text { business processes }\end{array}$ & & & \\
\hline $\begin{array}{l}\text { standardize the monitoring } \\
\text { and control process between } \\
\text { the branch leaders and } \\
\text { management }\end{array}$ & $\begin{array}{l}\text { implement integration } \\
\text { activities and organizational } \\
\text { climate study }\end{array}$ & & \\
\hline $\begin{array}{l}\text { Accompaniment and } \\
\text { monitoring by each process } \\
\text { leader of the policies } \\
\text { associated with their area in } \\
\text { the hands of the commercial } \\
\text { manager }\end{array}$ & & & \\
\hline
\end{tabular}

Source: Own elaboration

Table 4

Pareto priority index

\begin{tabular}{|c|c|c|c|c|c|}
\hline Strategy & Strategy & $\begin{array}{l}\text { Probability of } \\
\text { success }\end{array}$ & $\begin{array}{c}\text { completion time } \\
\text { (years) }\end{array}$ & costs & PPI \\
\hline Training plan & $\$ 17.466 .487,50$ & $83,33 \%$ & 1 & $\$ 29.110 .812,50$ & $50 \%$ \\
\hline Delegation & 0 & 1 & 1 & $\$ 94.387 .352,31$ & $0 \%$ \\
\hline $\begin{array}{l}\text { Management } \\
\text { methodology of } \\
\text { the commercial } \\
\text { area }\end{array}$ & $\$ 56.632 .411,38$ & $\$ 0,93$ & $\$ 1,00$ & $\$ 94.387 .352,30$ & $56 \%$ \\
\hline $\begin{array}{l}\text { Virtual platform } \\
\text { improvement }\end{array}$ & 0 & 1 & 1 & $\$ 94.387 .352,31$ & $0 \%$ \\
\hline
\end{tabular}

In accordance with the above information, an execution methodology is proposed that impacts the commercial area of the Seguros del Estado Armenia, where the following goals are achieved:

-Increase the productivity of the external consultant by $10 \%$ by closely monitoring their production figures, as well as their document management.

-Reduce poor quality costs by $40 \%$.

-Increase the relationship between the main actors of the production chain.

\section{Conclusions}

The current ways of managing the external sales force are a source of reprocessing and financial losses, because the monitoring, knowledge and communication channel are not adequate, which is why internal and external customer disagreements increase and thus same costs associated with the quality of the process. 
The implementation of strategic tools such as PEYEA, VESTER and the functional models of black box and transparent box, allow to know the reality of the company considering internal and external variables, with which it is possible to give a focus on decision making to when implementing new strategies or managing changes, since it is possible to extract from different dimensions the real problems and the position of the company in a context, resulting in a very precise diagnosis and a lower probability of failure.

The area in charge of commercial management has shortcomings in the monitoring of businesses and the external sales force, this due to the lack of standardization of good practices and methodology for the management of all the variables of the commercial team.

Training difficulties are identified at a technical and administrative level by the external sales force, which is a source of reprocessing around the organization's document filing, compilation of technical information on businesses and the constitution of commercial proposals for clients. which is a reflection of the opportunities for improvement from the management point of view in the branch's commercial area.

The implementation of the management model framed in the quality of Juran allows to identify the best strategies for the organization today based on the Pareto priority index, which defines the strategy in time, feasibility and financial impact of the strategy for the organization.

The methodology includes the implementation of monitoring formats and an adaptation in the communication channels of the existing personnel in order to optimize processes.

The first stage should consider the achievement of a quality team, where the communication channels and the interaction between the main actors in the core business processes are strengthened. This must be viewed both vertically and horizontally, which is why key personnel must also be integrated into the management of the State Insurance branch.

In accordance with the foregoing, it is suggested to consider in this quality group the commercial manager, who does all the management related to the sales force. In addition, technical analysts and portfolio personnel should also be considered in this team, since they are crucial in the follow-up, underwriting and issuance processes (they are the first filter of each process or business presented by the sales force, hence the importance of streamlining and strengthening communication channels). Finally, in this team we find the branch manager, who can streamline, leverage and support the various processes from his management and knowledge of the business with a strategic visual.

The manager must hold a monthly management meeting at the branch where the management of the commercial manager is presented on the advisors and operational issues of the office in all areas. Additionally, you must participate in the various planning spaces depending on the particularities that are considered. This seeks to provide strategic support effectively in the spaces that are really required.

\section{Bibliografic references}

Ackoff, R. (2005). Un concepto de planeación de empresas. México: Limusa.

Álvarez Martínez, R. E., \& Rebosa Álvarez, L. F. (2004). Calidad y Competitividad: la administración y la calidad. Administración para el diseño, 12-28.

Ansoff, H. I. (1985). La Estrategia De La Empresa. Barcelona: Orbis.

Blanco, M. G. (2008). El empleo del Modelo de Gestión de la Calidad Total en el sector de la distribución comercial en España : El caso de Mercadona. Universia, Business Review.

David, F. (2003). Conceptos de Administración Estratégica. En F. R. David, Conceptos de Administración Estratégica. México: Ed Pearson Prentice Hall 9ạ edición. 
Dinero. (8 de Marzo de 2017). Revista Dinero. Obtenido de https://www.dinero.com/edicionimpresa/negocios/articulo/aseguradoras-internacionales-llegan-a-colombia/248135

Evans, J., \& Lindsay, W. (2010). Administración y control de la calidad. Mexico D.F: Cengage Learning.

Fasecolda. (2018). Estadísticas del sector. Obtenido de http://www.fasecolda.com/index.php/fasecolda/estadisticas-del-sector/

Geus, A. D. (1998). La Empresa Viviente y habitos para sobrevivir en un ambiene de negocios turbulentos. Barcelona, España : Granica .

Goodstein, L., Nolan, T., \& William, P. (1998). Planeación Estratégica Aplicada. McGraw Hill.

Gryna, F., Chua, R., \& Defeo, J. (2007). Método Juran, análisis y planeacion de la calidad. Mexico D.F.: McGrawHill Interamericana.

Haik, Y., \& Tamer, S. (2011). Engineering Design Process. Estados Unidos: Cengage Learning.

Medina, J. N., \& Gozalbes Ballester, M. (1996). Juran On Quality by Design.

Norton, R., \& Kaplan, D. (1996). Cuadro de mando integral. En R. y. Norton, Cuadro de mando integral. Barcelona: Gestión 2000.

Portafolio. (08 de Septiembre de 2019). Portafolio. Sector asegurador crecerá entre 8 y10\% este año: fitch. Obtenido de https://www.portafolio.co/economia/finanzas/sector-asegurador-crecera-entre-8-y-10-esteano-fitch-533360

Porter, M. (2008). Las cinco fuerzas competitivas que le dan forma a la estrategia. Harvard Business Review, 120.

Rengarajan, S., Moser, R., \& Narayanamurthy, G. (2021). Strategy tools in dynamic environments - An expertpanel study. Technological Forecasting and Social Change, 165, 1-14.

Revista Semana . (28 de 09 de 2020). Revista Semana . Obtenido de https://www.semana.com/contenidoseditoriales/seguros/articulo/seguros-del-estado-protege-el-patrimonio-de-los-colombianos/202000/

Romo Morales, G., \& Márquez de León , E. (2014). Strategic management vs. Strategic analysis. A conceptual discussion through the case study of a higher education institution. Pensamiento y gestión, 265-288.

Wheelen, T., \& Hunger, D. (2013). Administración Estratégica y Política de Negocios. México: Pearson.

Esta obra está bajo una Licencia Creative Commons

Attribución-NoCommercial 4.0 International

(cc) EY-NC 